\title{
When are eradication campaigns successful? A test of common assumptions
}

\author{
Therese Pluess $\cdot$ Ray Cannon • Vojtěch Jarošík • \\ Jan Pergl • Petr Pyšek · Sven Bacher
}

Received: 7 April 2011/Accepted: 18 December 2011/Published online: 25 January 2012

(C) Springer Science+Business Media B.V. 2012

\begin{abstract}
Eradication aims at eliminating populations of alien organisms from an area. Since not all eradications are successful, several factors have been proposed in the literature (mainly by referring to case studies) to be crucial for eradication success, such as infestation size or reaction time. To our knowledge, however, no study has statistically evaluated which factors affect eradication success and attempted to determine their relative importance. We established a unique global dataset on 136 eradication campaigns against 75 species (invasive alien invertebrates, plants and plant pathogens) and statistically tested whether
\end{abstract}

Electronic supplementary material The online version of this article (doi:10.1007/s10530-011-0160-2) contains supplementary material, which is available to authorized users.

T. Pluess $(\bowtie) \cdot$ S. Bacher

Department of Biology, Ecology and Evolution Unit, University of Fribourg, Chemin du Musée 10,

1700 Fribourg, Switzerland

e-mail: therese.pluess@gmx.ch

R. Cannon

The Food and Environment Research Agency,

Sand Hutton, York YO41 1LZ, UK

V. Jarošík · P. Pyšek

Department of Ecology, Faculty of Science,

Charles University, 12801 Prague 2, Czech Republic

V. Jarošík · J. Pergl · P. Pyšek

Academy of Sciences of the Czech Republic, Institute of Botany, 25243 Průhonice, Czech Republic the following factors, proposed by others were significantly related to eradication success: (1) the reaction time between the arrival/detection of the organism and the start of the eradication campaign; (2) the spatial extent of the infestation; (3) the level of biological knowledge of the organism; and (4) insularity. Of these, only the spatial extent of the infestation was significantly related to the eradication outcome: local campaigns were more successful than regional or national campaigns. Reaction time, the level of knowledge and insularity were all unrelated to eradication success. Hence, some factors suggested as being crucial may be less important than previously thought, at least for the organisms tested here. We found no differences in success rates among taxonomic groups or geographic regions. We recommend that eradication measures should generally concentrate on the very early phase of invasions when infestations are still relatively small.

Keywords Eradication success - Invasive species · Contingency planning · Pest Risk Analysis - Invasive species management $\cdot$ Biological invasions

\section{Introduction}

Despite increased research efforts about the impact of invasive species (Winter et al. 2009; Vilà et al. 2009; Nentwig et al. 2010), their economic costs (Kettunen et al. 2009), and intensive exploration of management 
options (Hulme 2006, 2009; Pyšek and Richardson 2010), little is known about how environmental settings, species traits and other contingent factors affect the outcome of management actions against invasive species. Key management options for invasive species include: prevention, eradication, containment, and various forms of mitigation (Pyšek and Richardson 2010; Shine et al. 2010). Among these, eradication represents the ultimate course of action, but often also the most expensive solution. Eradication is the application of control measures aiming at extirpating an entire population of a pest from an area (FAO 2007) or from a management unit (Pyšek and Richardson 2010). Recently, there has been a renewed interest in eradicating invasive species, following a period when the prevailing view was that the elimination of a pest population was very seldom achievable (Simberloff 2009; Pyšek and Richardson 2010).

Much research is being published suggesting decision-tools for an efficient application of control measures in specific situations such as the infestation of the gypsy moth (Lymantria dispar) in the United States (Bogich et al. 2008), the campaigns against the brown rat (Rattus norvegicus) in South Georgia, Southern Ocean (Robertson and Gemmell 2004) or against bitterweed (Helenium amarum) in Australia (Rout et al. 2009a, b; Regan et al. 2006). However, these are case-specific decision-aid tools that do not allow drawing general conclusions as to which factors are important for eradicating a pest population.

The difficulty is that it is not always clear at first what is the most appropriate way to react to a new pest incursion. When responsible authorities are confronted with a new infestation, they need to know which factors are most important for enhancing the likelihood of eradicating the unwanted organism so that an appropriate control strategy can be designed and implemented. A number of reviews of eradication campaigns has been published in the last two decades, comparing the outcomes for various taxonomic groups based on descriptive case studies (Clout and Veitch 2002; Simberloff 2003b, 2009, Myers et al. 2000; Genovesi 2007; Bomford and O'Brien 1995), or assessing taxonomic groups separately, such as plants (Mack and Lonsdale 2002; Rejmánek and Pitcairn 2002; Simberloff 2003a), mammals (Courchamp et al. 2003), moths (Brockerhoff et al. 2010), invertebrates (Dahlsten and Garcia 1989), plant pathogens (Sosnowski et al. 2009) or vertebrates and plants (Genovesi 2005).
All of these reviews drew general conclusions as to why eradication campaigns fail or succeed based on evidence from the case studies they reviewed and suggested a number of factors relating to eradication success. However, evidence from case studies can be equivocal as to which factors may be relevant for eradication success. There is thus a need to take a quantitative approach that assembles data on as many cases as possible, including both successful and failed eradications. By applying statistical analyses it may be possible to identify general principles or critical factors associated with successful eradication campaigns. In the following, four of the success factors proposed in the literature which can be quantified and therefore be subject to statistical analyses are discussed and hypotheses formulated for subsequent analyses.

Several authors consider that a rapid response, following the first detection of the invasive organism, is crucial for eradication success, because it prevents the organism from spreading (Clout and Veitch 2002; Simberloff 2003b, 2009, Myers et al. 2000; Genovesi 2007; Bomford and O'Brien 1995). It is also assumed that small and isolated populations are easier to eradicate, and that a rapid reaction prevents further population growth and spread (Liebhold and Bascompte 2003; Clout and Veitch 2002; Mack and Lonsdale 2002; Brockerhoff et al. 2010). As a consequence, it is expected that infestations occupying a small area are easier to eradicate, because measures can be applied more thoroughly and are more likely to be cost effective at smaller scales. Brockerhoff et al. (2010) examine this type of approach for six moth species, all forest pests in New Zealand and found a strong positive relationship between the size of the affected area and eradication costs. Furthermore, Allee effects favoring eradication might be stronger if the pest population and the area it occupies are still small (Vercken et al. 2011; Liebhold and Bascompte 2003).

Another argument often put forward is that detailed biological knowledge concerning an organism is needed in order to design appropriate control measures; the target species must be studied well enough to suggest vulnerabilities (Simberloff 2009). Examples are the use of super-Judas goats (i.e. the release of sterilized and hormone-treated female goats) to eradicate goats from the Galapagos Islands or the development of pheromone lure traps against the sea lamprey (Petromyzon marinus) in the Great Lakes (Simberloff 2009). Another example is the eradication 
of the painted apple moth (Teia anartoides) in New Zealand, were a combination of tactics was used, including the sterile insect technique (Suckling et al. 2007). We assume that understanding the biology of the species translates into better plans to eradicate it. This implies that campaigns with species-specific eradication or contingency plans should be more successful than those following only generic plans.

Many eradications are initiated on islands because it is assumed that eradication campaigns carried out on islands might be more likely to succeed than those on mainland sites (Courchamp et al. 2003). At least for vertebrates, especially mammals, the most notable successes were achieved on isolated island populations (Clout and Veitch 2002; Courchamp et al. 2003). Successful campaigns have also targeted insects on small islands, beginning with the tsetse fly (Glossina spp.) campaign on Principe or the screw-worm (Cochliomyia hoinivorax) campaign on Curaçao (Simberloff 2008). Eradication of plants from islands appears to be, in quantitative terms, less successful: as illustrated by a review of the outcomes of plant eradication efforts on the Galapagos Islands (Gardener et al. 2010), where of 30 eradication projects covering 23 potentially invasive plant species with limited distributions on four Galapagos Islands, only four were successful (but see Simberloff et al. 2011).

The present study statistically analyzes four factors proposed in the literature (reaction time, the extent of the infestation, the knowledge of the invading species' biology, and whether the campaign was on an island or the mainland) for their association with eradication success. These factors were tested on data of eradication campaigns against invasive alien invertebrates, plants and plant pathogens (bacteria, fungi, and viruses/viroids) that are of economic (e.g. agricultural) but also of ecological importance. Eradication of plant pest populations is most often attempted in the agricultural sector (i.e. the repeated eradication of the Colorado beetle in the United Kingdom; Bartlett 1979). Nonetheless, there is a strong need to improve the decision-making process in plant protection in both economic and ecological environments and especially for newly emerging pest species (Opstal and Sunley 2009). In particular, the following four hypotheses were tested:

(i) A rapid response to a pest incursion increases the chances of eradication success. (ii) Small infestations are easier to eradicate than larger ones.

(iii) Biological knowledge and a high level of preparedness to react to an incursion increase the chances of eradication success.

(iv) Island eradications are more likely to succeed than those carried out on mainland areas.

It was also tested, whether there are differences in the eradication success among organisms from different Kingdoms and among biogeographic regions.

\section{Materials and methods}

Data collection

The scientific and grey literature was searched for information about eradications of invasive alien invertebrates, plants and plant pathogens, published in scientific publications, eradication reports, other technical reports, pest alerts and online press releases from national plant protection organizations (NPPOs). Information about eradication campaigns is often difficult to obtain from published literature (Simberloff 2009), and the European project PRATIQUE (Baker et al. 2009) provided a unique and unprecedented opportunity to access unpublished (expert) knowledge. Thus national and regional plant protection organizations were important sources of information, and pest managers from NPPOs from Europe, North America, Australia and New Zealand were contacted to provide examples and detailed information about eradication campaigns from their countries.

We collected data on 136 plant pest and weed eradication campaigns from 5 Kingdoms, of which 70 were targeted against invertebrates (belonging to 34 species, mostly insects), 19 against bacteria (six species or subspecies), 13 against fungi (10 species), 18 against plants (18 species) and 16 against viruses/ viroids (seven species or subspecies), see Table 1 for a species list. Information from 26 countries, divided into 74 European, 39 American and 23 Australasian campaigns was collated. The campaigns had been launched between 1914 and 2009, with the large majority (71\%) being started after 1990 (Fig. 1a). The campaigns were carried out in a variety of habitat types including wetland, grassland, woodland, agricultural, horticultural or domestic habitats and constructed, 
Table 1 List of species against which eradication campaigns were launched, with average success rates per species and Kingdom and number of case studies in the dataset

\begin{tabular}{|c|c|c|c|}
\hline Kingdom & Species & $\begin{array}{l}\% \\
\text { Success }\end{array}$ & $\begin{array}{l}\# \\
\text { Cases }\end{array}$ \\
\hline \multirow{34}{*}{$\begin{array}{l}\text { Animalia } \\
\qquad=\text { invertebrates) }\end{array}$} & Anoplophora chinensis & 75 & 4 \\
\hline & $\begin{array}{l}\text { Anoplophora } \\
\text { glabripennis }\end{array}$ & 10 & 10 \\
\hline & Anthonomus grandis & 50 & 4 \\
\hline & Aphelenchoides besseyi & 0 & 1 \\
\hline & Bactrocera cucurbitae & 100 & 1 \\
\hline & Bactrocera dorsalis & 100 & 1 \\
\hline & Bactrocera tryoni & 100 & 2 \\
\hline & Bemisia tabaci & 50 & 2 \\
\hline & Bryobialago dechiana & 0 & 1 \\
\hline & $\begin{array}{l}\text { Bursaphelenchus } \\
\text { hunanensis }\end{array}$ & 100 & 1 \\
\hline & $\begin{array}{l}\text { Bursaphelenchus } \\
\text { xylophilus }\end{array}$ & 0 & 1 \\
\hline & Ceratitis capitata & 100 & 3 \\
\hline & Cydia pomonella & 0 & 1 \\
\hline & Cylas formicarius & 100 & 1 \\
\hline & Diabrotica virgifera & 17 & 6 \\
\hline & Diaspidiotus perniciosus & 100 & 1 \\
\hline & Epilachna varivestis & 100 & 1 \\
\hline & $\begin{array}{l}\text { Frankliniella } \\
\text { occidentalis }\end{array}$ & 50 & 2 \\
\hline & Hyphantria cunea & 100 & 1 \\
\hline & $\begin{array}{l}\text { Leptinotarsa } \\
\text { decemlineata }\end{array}$ & 100 & 3 \\
\hline & Liriomyza huidobrensis & 100 & 1 \\
\hline & Liriomyza trifolii & 100 & 1 \\
\hline & Lymantria dispar & 40 & 5 \\
\hline & Opogona sacchari & 50 & 2 \\
\hline & Orchidophilus aterrimus & 0 & 1 \\
\hline & Orgiya thyellina & 100 & 1 \\
\hline & Parlatoria blanchardi & 67 & 3 \\
\hline & Pectinophora gossypiella & 0 & 3 \\
\hline & Peltoschema suturalis & 100 & 1 \\
\hline & $\begin{array}{l}\text { Rhynchophorus } \\
\text { ferrugineus }\end{array}$ & 0 & 1 \\
\hline & Saperda candida & 0 & 1 \\
\hline & Spodoptora litura & 100 & 1 \\
\hline & Stephanitis takeyai & 0 & 1 \\
\hline & Teia anartoides & 0 & 1 \\
\hline $\begin{array}{l}\text { Animalia } \\
\text { (= invertebrates) } \\
\text { average/total }\end{array}$ & & 56 & 70 \\
\hline
\end{tabular}

Table 1 continued

\begin{tabular}{|c|c|c|c|}
\hline Kingdom & Species & $\begin{array}{l}\% \\
\text { Success }\end{array}$ & $\begin{array}{l}\# \\
\text { Cases }\end{array}$ \\
\hline \multirow[t]{6}{*}{ Bacteria } & $\begin{array}{l}\text { Clavibacter } \\
\text { michiganensis } \\
\text { michiganensis }\end{array}$ & 100 & 2 \\
\hline & $\begin{array}{l}\text { Clavibacter } \\
\quad \text { michiganensis } \\
\text { sepedonicus }\end{array}$ & 100 & 1 \\
\hline & Erwinia amylovora & 25 & 4 \\
\hline & Ralstonia solanacearum & 71 & 7 \\
\hline & $\begin{array}{r}\text { Xanthomonas } \\
\text { axonopodis }\end{array}$ & 100 & 2 \\
\hline & Xanthomonas citri & 67 & 3 \\
\hline Bacteria average/total & & 77 & 19 \\
\hline \multirow[t]{10}{*}{ Fungi } & Ceratocystis ulmi & 0 & 1 \\
\hline & Cryphonectria parasitica & 0 & 2 \\
\hline & Eutypella parasitica & 0 & 1 \\
\hline & Glomerella acutata & 0 & 2 \\
\hline & $\begin{array}{l}\text { Mycosphaerella } \\
\text { dearnessii }\end{array}$ & 0 & 1 \\
\hline & Mycosphaerella fijiensis & 100 & 1 \\
\hline & Puccinia horiana & 50 & 2 \\
\hline & Seiridium cardinale & 0 & 1 \\
\hline & Ustilago maydis & 100 & 1 \\
\hline & Venturia inaequalis & 100 & 1 \\
\hline Fungi average/total & & 35 & 13 \\
\hline \multirow[t]{18}{*}{ Plantae } & Ageratina adenophora & 0 & 1 \\
\hline & Ageratina riparia & 0 & 1 \\
\hline & Araujia sericifera & 0 & 1 \\
\hline & Cenchrus echinatus & 0 & 1 \\
\hline & $\begin{array}{l}\text { Ceratophyllum } \\
\text { demersum }\end{array}$ & 100 & 1 \\
\hline & Chromolaena odorata & 0 & 1 \\
\hline & Citharexylum gentryi & 100 & 1 \\
\hline & Cortaderia jubata & 0 & 1 \\
\hline & Cortaderia selloana & 0 & 1 \\
\hline & $\begin{array}{l}\text { Heracleum } \\
\quad \text { mantegazzianum }\end{array}$ & 0 & 1 \\
\hline & Ludwigia uruguayensis & 100 & 1 \\
\hline & Lysichiton americanus & 0 & 1 \\
\hline & Orobanche ramosa & 0 & 1 \\
\hline & Pueraria phaseoloides & 100 & 1 \\
\hline & Rhizophora mangle & 100 & 1 \\
\hline & Rubus adenotrichos & 100 & 1 \\
\hline & Rubus glaucus & 100 & 1 \\
\hline & Rubus megalococcus & 100 & 1 \\
\hline Plantae average/total & & 44 & 18 \\
\hline
\end{tabular}


Table 1 continued

\begin{tabular}{|c|c|c|c|}
\hline Kingdom & Species & $\begin{array}{l}\% \\
\text { Success }\end{array}$ & $\begin{array}{l}\# \\
\text { Cases }\end{array}$ \\
\hline \multirow[t]{7}{*}{ Virus(-like) } & $\begin{array}{l}\text { Beet necrotic yellow vein } \\
\text { virus }\end{array}$ & 0 & 1 \\
\hline & $\begin{array}{l}\text { Chrysanthemum stem } \\
\text { necrosis virus }\end{array}$ & 100 & 1 \\
\hline & Citrus tristeza virus & 50 & 2 \\
\hline & $\begin{array}{l}\text { Impatiens necrotic spot } \\
\text { virus }\end{array}$ & 100 & 1 \\
\hline & Plum pox virus & 13 & 8 \\
\hline & Tomato spotted wilt virus & 100 & 2 \\
\hline & $\begin{array}{l}\text { Tomato yellow leaf curl } \\
\text { virus }\end{array}$ & 100 & 1 \\
\hline $\begin{array}{l}\text { Virus(-like) } \\
\text { average/total }\end{array}$ & & 66 & 16 \\
\hline Total average & & 53 & 136 \\
\hline
\end{tabular}

industrial or other artificial habitats, see Fig. 1b) for more details. The dataset was dominated by campaigns against organisms in artificial habitats (62\%) with 21 campaigns being carried out exclusively in protected areas (e.g. glasshouses). Most other campaigns were carried out in a variety of different habitat types, including (semi-)natural habitats (Fig. 1b).

A campaign was considered a success if successful eradication of the organism had been officially declared; otherwise it was treated as failure. Campaigns on-going as of December 2009, were also considered as having failed, since successful eradication had not yet been declared. A list of all cases and tested factors is given in Table A1 as Supplementary Material.

\section{Explanatory variables}

For each eradication campaign, the following variables, corresponding to the four hypotheses, were considered (see Table 2 for their detailed description).

(i) Reaction time: The time elapsed between the arrival of an organism and the beginning of management measures was counted in months. If the arrival date was not known, the date of first record was taken as starting point.

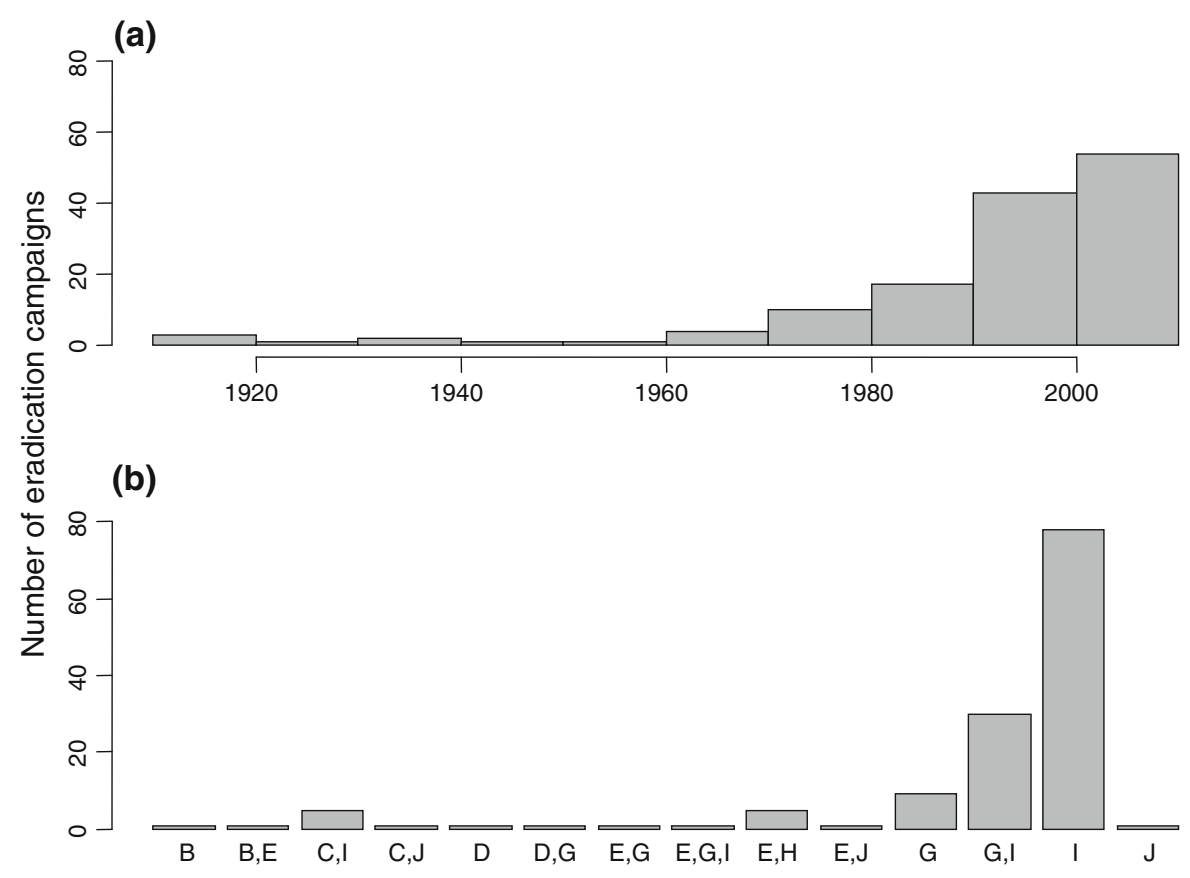

Fig. 1 Frequency distribution of a the starting year of 136 eradication campaigns against invasive alien invertebrates, plants and plant pathogens and $\mathbf{b}$ the type of habitats affected by these campaigns. Habitat types are following the EUNIS habitat classification by Davies and Moss (2003; http://eunis.eea.europa.eu/habitats.jsp): $B$ : coastal habitats; $C$ : inland surface waters; $D$ : mires, bogs and fens; $E$ : grasslands, and lands dominated by forbs, mosses or lichens; $G$ : woodland, forest and wooded land; $H$ : inland unvegetated or sparsely vegetated habitats; $I$ : regularly or recently cultivated agricultural, horticultural and domestic habitats (including glasshouses); $J$ : constructed, industrial and other artificial habitats 
Table 2 Description of dependent variable, explanatory variables (potential success factors for plant pest and weed eradications) and random factors

Dependent variable

1) Successful eradication The eradication campaign was successful, which was confirmed by surveys over a time period relevant for the life-cycle of the organism, the campaign stopped, $\mathrm{N}=66$

0) Failed eradication All other campaigns, $\mathrm{N}=70$

Explanatory variables (potential success factors)

(i) Reaction time The time elapsing between the arrival (or detection) of the organism and the start of the eradication campaign, counted in months

(ii) Size of infested area

(1) Local One rather small, isolated infestation focus, $\mathrm{N}=51$

(2) Regional A larger area, but never the entire country, was affected including more than one and up to ten infestation foci, $\mathrm{N}=32$

(3) National A campaign in an entire country, usually including more than ten infestation foci. For campaigns in the United States and Canada, states or provinces were classified as "national", $N=44$

(4) International

A campaign involved several countries (or states or provinces in the USA and Canada), the number of infestation foci is irrelevant, $\mathrm{N}=9$

(iii) Biological knowledge and preparedness to act

(0) None

(1) Low

(2) Medium

(3) High

(iv) Insularity

Island Eradication on an island (including New Zealand), N = 40

Mainland Eradication on a continent, $\mathrm{N}=96$

Random factors

Kingdom Latin name of taxonomic Kingdom

Name Species name

Biogeographic region Name of the continent the eradication took place

(ii) Infestation size: To account for the spatial extent of an eradication campaign, a semi-quantitative spatial variable at four levels was introduced.

1) Local; one small, isolated infestation focus, for example a finding in an individual glasshouse, a crop field, a nursery or on a group of trees.

2) Regional; eradication measures taken at a regional scale, but within a country, including more than one and up to ten local infestation foci.

3) National; the campaign was addressed against an organism across an entire country, including more than ten local infestation foci. For campaigns in the United States and Canada, measures affecting an entire state or province were also classified as "national". This classification was chosen assuming that campaigns within one country/state/province should be easier to manage than international campaigns because they largely fall under one jurisdiction.

4) International; if several countries (or states or provinces in the case of the USA and Canada) were collectively managing an organism.

While this categorization of scale was easily derived from the description of the situation in the literature, a more precise quantitative measurement of the infestation area $\left(\right.$ in $\mathrm{km}^{2}$ ) was rarely available. 
(iii) Biological knowledge and preparedness to act: As a measure of the level of biological knowledge, the type of documented information available at the moment of the infestation was ranked, assuming that simply having a pest notice or fact sheet would be less informative than an entire Pest Risk Analysis (PRA; FAO 2004) and that a PRA would be less informative than a detailed contingency or eradication plan. It was also assumed that different types of documentation will translate into different levels of preparedness of authorities to appropriately react to an infestation: Contingency or eradication plans would indicate a higher level of preparedness than a PRA or a pest notice, which both usually do not detail pest risk management measures. The degree of knowledge about the species and the readiness of authorities to eradicate an incursion were thus ranked as follows:

0) No knowledge/preparedness; information about the species and possible management measures were collected and evaluated only after the incursion.

1) Low knowledge/preparedness; pest alerts, pest notices or similar information were available when the pest was detected, but neither a PRA nor a contingency plan were available at that incursion.

2) Medium knowledge/preparedness; a PRA for the species or a generic contingency plan on how to react to an infestation in general was available at the incursion.

3) High knowledge/preparedness; a speciesspecific contingency/eradication plan was available at the incursion.

(iv) Insularity. It was distinguished whether a campaign was carried out on an island (including New Zealand) or a continent.

Reaction time, spatial extent and knowledge/preparedness were coded as numerical variables, while insularity was a factor in the model.

Analyses

\section{General approach}

The relationship between the four factors and eradication success was tested with Generalized Linear
Mixed Models (GLMM; Bolker et al. 2009). We used the function glmer from the R package lme4 (version 0.999375-28, Bates et al. 2008). The outcome of each campaign (success/failure) served as the dependent variable and the factors expected to affect the outcome were included as fixed factors: (i) "reaction time", (ii) "spatial extent", (iii) "biological knowledge \& preparedness" and (iv) "insularity".

To allow direct comparisons of their relative importance, all numerical variables (i, ii, iii) were scaled prior to the analyses, using the function scale from the R package base (version 2.8.1, R Development Core Team 2008). Collinearity between the success factors was low (Spearman rank correlation coefficients, all $r<0.3$; Zuur et al. 2009).

The outcomes of campaigns against related species can not be considered as independent, because they are likely to share similar characteristics (Manchester and Bullock 2000). Likewise, eradication campaigns in the same biogeographic region may have similar, i.e. dependent outcomes. We accounted for this by including the taxonomic Kingdom of the organism (Animalia, Bacteria, Fungi, Plantae and viruses) and the biogeographic region in which the campaign was conducted (America, Australasia and Europe) as random factors in the models. Additionally, the outcome of eradication campaigns directed against the same pest species can be expected to be related due to intrinsic characteristics of the species concerned. We corrected for this non-independence by including the species as a random factor, nested within Kingdom.

\section{Model selection}

Model selection for ecological inference was done in an information theoretic framework (Burnham and Anderson 2002). In a first step, the random part of the model was chosen (Zuur et al. 2009). For that, the AIC of models with all possible combinations of random factors were compared (i.e. no random factor, only species, only Kingdom, only biogeographic region, species nested within Kingdom, species and biogeographic region, Kingdom and biogeographic region, and species nested within Kingdom and geographical region). Each of these models included all four fixed effects. The structure of the random effects of the bestfitting model, i.e. the one with the lowest AIC, or, if $\triangle \mathrm{AIC}<2$, the most parsimonious model was chosen for further analysis (Zuur et al. 2009). 
After the random part was chosen, the fixed factors that best explained variation in eradication success were determined. For that, the AIC of models with all possible combinations of the four fixed factors were calculated. All models conforming to two rules were selected for ecological inference (Richards 2008): First, all models with a $\Delta$ AIC value $\leq 6$ were selected for parameter estimation. This threshold of 6 is much higher than the widely-accepted rule-of-thumb of selecting all models with a $\triangle \mathrm{AIC}$ value $\leq 2$ proposed by Burnham and Anderson (2002), but it recently has been demonstrated that the most parsimonious model, defined as the one with the lowest expected KullbackLeibler distance, being a measure of the mean discrepancy between the model and the unknowable truth, may be missed otherwise (Richards 2005). As a second rule, a model was only selected if its AIC value was less than the AIC value of all the simpler models within which it is nested in order to avoid selecting overly complex models (Richards 2008). The reasoning for this is that if an additional parameter provides little or no increase in model fit, then the more complex model with the additional parameter will have a $\triangle$ AIC-value less or equal to 2 to the simpler model; thus the more complex model fits the data equally well as the simpler model. However, in such cases the more complex model with the additional parameter should not be considered for ecological inference, since nothing is explained by the additional complexity (Burnham and Anderson 2002; Richards 2008).

Finally, the values of all four parameters were estimated by model averaging among the set of candidate models chosen by model selection (function modavg from the package AICcmodavg, version 1.18 in R; Mazerolle 2011). A parameter can be considered as having a significant effect if the confidence interval does not include zero.

\section{Results}

Considering each case as independent, about half of the eradication campaigns (49\%) were declared as successful in terms of eliminating the pest from the targeted area.

There were no obvious differences in the eradication success among Kingdoms (Fig. 2a) or biogeographic regions (Fig. 2b). This was supported by

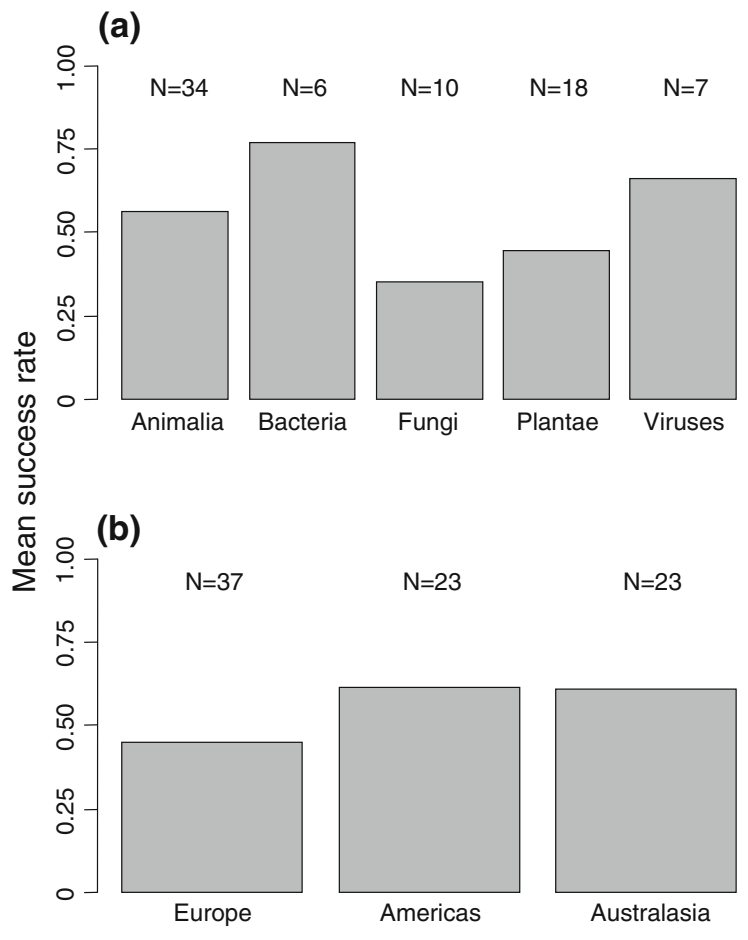

Fig. 2 Mean success rate of eradication campaigns against invasive alien invertebrates, plants and plant pathogens, across $\mathbf{a}$ five taxonomic Kingdoms and $\mathbf{b}$ three biogeographic regions. Pseudo-replication is corrected for by calculating the average success rate for each species. Depicted are the means of these species-averages for each Kingdom or biogeographic region, respectively. Animalia $=$ invertebrate animals

logistic regressions of the eradication success with Kingdom or biogeographic region as explanatory variables and the species as random factor (analysis of deviance; Kingdom: $\chi^{2}=4.58$, d.f. $=4, P=$ 0.333 , biogeographic region: $\chi^{2}=3.50$, d.f. $=2$, $P=0.174)$. It was also tested if the taxonomic Kingdom or the biogeographic region explained a significant proportion of variation in the data by including them as random factors in models with all other explanatory variables. However, all models including Kingdom or biogeographic region fitted the data significantly worse according to the AIC $(\Delta \mathrm{AIC}>2)$ than a model with only the species as random factor. Thus, only species identity was kept as random factor in the following model selection procedure.

Eleven of the 16 fitted models had a $\Delta$ AIC-value $\leq 6$ (Table 3); the other models were discarded for ecological inference according to the first rule of model selection. The best-fitting model (m2) 
contained only infestation size to explain eradication success (Table 3). The seven next best-fitting models all also contained infestation size plus additional explanatory variables (Table 3 ). They were discarded from ecological inference according to the second rule of model selection, because they represent extensions of a simpler model (m2) and had a worse fit. Apart from the best-fitting model $(\mathrm{m} 2)$, only three other models were retained for ecological inference: a model with no explanatory variable ( $\mathrm{m} 1)$, and models with either only the level of preparedness (m5) or the reaction time (m4; Table 3). However, these latter three models all had $\Delta \mathrm{AIC}$-values $>4$ and were thus not well supported (AIC weights $\leq 3 \%$; Table 3 ). Parameter averaging among the four retained models $(\mathrm{m} 2, \mathrm{~m} 1, \mathrm{~m} 4$ and $\mathrm{m} 5)$ revealed that only the effect of infestation size was significantly different from zero (model-averaged estimate $=-0.56 ; 95 \%$ unconditional confidence interval of the scaled estimate: $0.14,-0.98)$; confidence intervals for the level of preparedness $(0.66,-0.16$; average $=0.25)$ and for the reaction time $(0.23,-0.57$; average $=-0.17)$ included zero. Insularity never was in a model considered for ecological inference. Thus, infestation size was the only parameter that received strong support to affect eradication success. The relationship between the four tested potential factors for eradication success and the outcome of campaigns is depicted in Fig. 3.

\section{Discussion}

Of all stipulated success factors tested here, only the extent of the infestation was important for eradication outcome. Not unexpectedly, local infestations were easier to eradicate than regional or national ones. This is in accordance with a study of plant eradications in California, were the eradication of exotic plant infestations smaller than one hectare was usually possible, but the likelihood of eradication declined rapidly with increasing area, making the eradication of species occupying $>1,000$ ha very unlikely, given the resources typically committed to such operations (Rejmánek and Pitcairn 2002). Eradications at the local level might be easier because the infestation is

Table 3 Results of model selection

\begin{tabular}{|c|c|c|c|c|c|c|c|c|}
\hline Model & $\begin{array}{l}\text { Infestation } \\
\text { size }\end{array}$ & Insularity & $\begin{array}{l}\text { Reaction } \\
\text { time }\end{array}$ & $\begin{array}{l}\text { Knowledge and } \\
\text { preparedness }\end{array}$ & AIC & $\Delta \mathrm{AIC}$ & $\begin{array}{l}\text { AIC } \\
\text { weight }\end{array}$ & $\begin{array}{l}\text { Cumulative } \\
\text { AIC weight }\end{array}$ \\
\hline $\mathrm{m} 2(*)$ & $x$ & & & & 182.82 & 0 & 0.22 & 0.22 \\
\hline $\mathrm{m} 8$ & $x$ & & & $\times$ & 182.88 & 0.07 & 0.21 & 0.43 \\
\hline $\mathrm{m} 6$ & $\times$ & $x$ & & & 183.82 & 1.01 & 0.13 & 0.56 \\
\hline $\mathrm{m} 13$ & $\times$ & $x$ & & $\times$ & 184.13 & 1.32 & 0.11 & 0.67 \\
\hline $\mathrm{m} 7$ & $x$ & & $x$ & & 184.85 & 2.04 & 0.08 & 0.75 \\
\hline $\mathrm{m} 14$ & $\times$ & & $\times$ & $\times$ & 185.03 & 2.21 & 0.07 & 0.83 \\
\hline $\mathrm{m} 12$ & $x$ & $\times$ & $\times$ & & 185.86 & 3.05 & 0.05 & 0.87 \\
\hline $\mathrm{m} 16$ & $\times$ & $x$ & $\times$ & $\times$ & 186.3 & 3.49 & 0.04 & 0.91 \\
\hline $\mathrm{m} 1(*)$ & & & & & 186.98 & 4.17 & 0.03 & 0.94 \\
\hline m5 (*) & & & & $\times$ & 187.88 & 5.06 & 0.02 & 0.96 \\
\hline $\mathrm{m} 4(*)$ & & & $x$ & & 188.44 & 5.62 & 0.01 & 0.97 \\
\hline $\mathrm{m} 3$ & & $x$ & & & 188.98 & 6.17 & 0.01 & 0.98 \\
\hline $\mathrm{m} 11$ & & & $x$ & $\times$ & 189.55 & 6.73 & 0.01 & 0.99 \\
\hline $\mathrm{m} 10$ & & $x$ & & $\times$ & 189.96 & 7.14 & 0.01 & 0.99 \\
\hline $\mathrm{m} 9$ & & $x$ & $x$ & & 190.42 & 7.6 & 0 & 1 \\
\hline $\mathrm{m} 15$ & & $x$ & $x$ & $x$ & 191.64 & 8.82 & 0 & 1 \\
\hline
\end{tabular}

$\times$ Factors present in the models. Models are ordered according to their AIC values

$\triangle A I C$ : Difference between the AIC of the best-fitting model and the current model. AIC weight: The Akaike weights; these measures indicate the level of support (i.e. weight of evidence) in favor of any given model being the most parsimonious among the candidate model set. * Models selected for parameter estimation 
(a)

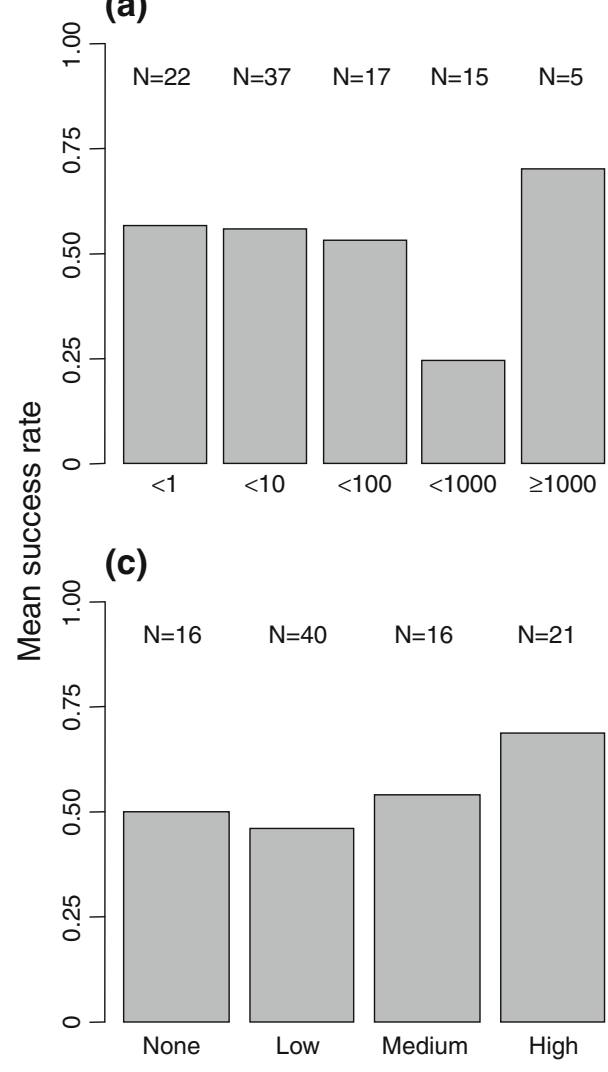

(b)

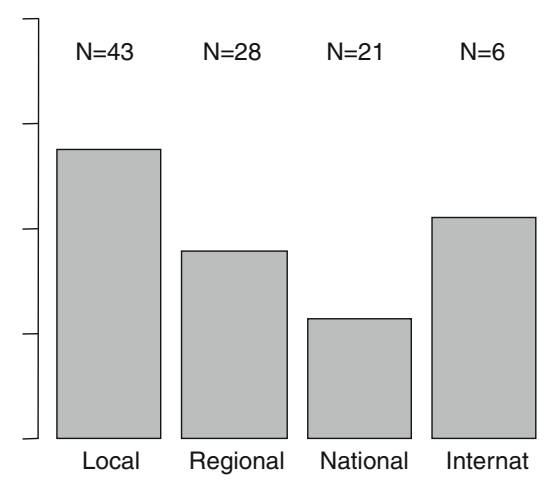

(d)

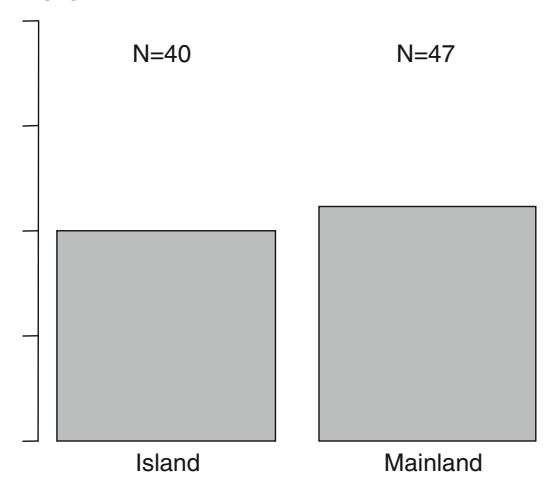

Fig. 3 Mean success rates of eradication campaigns against invasive alien invertebrates, plants and plant pathogens, depending on a reaction time in months, $\mathbf{b}$ the infestation size at four levels, $\mathbf{c}$ four different levels of biological knowledge and preparedness to react and $\mathbf{d}$ whether the eradication took place

isolated and delimitation is therefore more straightforward. Small-sized populations may not yet have become fully established, may not have spread and may be more prone to Allee effects than larger populations (Liebhold and Bascompte 2003). For example, a recent study found evidence that a critical patch size exists across the invasion front of the European gypsy moth (Lymantria dispar) in the United States, below which pest populations cannot persist due to Allee effects (Vercken et al. 2011). Such a mechanism could be useful for invasive species management (Tobin et al. 2011), because it implies that not every single individual of a target population needs to be removed, the population only needs to be reduced below a critical patch size when extinction is inevitable. However, it is yet unclear if the concept of the critical patch size is applicable to many species. A recent study on Allee effects during establishment of on an island or the mainland. Pseudo-replication is corrected for by calculating the average success rate for each species. Depicted are the means of these species-averages for the four potential success factors

natural populations suggests that strong Allee effects, a prerequisite of critical patch size, are rare in many animal taxa (Duncan, Blackburn, Rossinelli \& Bacher, unpublished data). In addition, targeting large infestations is more resource-demanding, hence eradicating a pest at the regional or even the national level might only be possible with a huge investment of resources (Brockerhoff et al. 2010; Rejmánek and Pitcairn 2002). The importance of the size of the infestation for eradication success suggests that eradication measures should concentrate on the early phase of the invasion when infestations are still relatively small. This also highlights the importance of delimiting the infestation quickly after its discovery, in order to have a solid basis for decision-making and investing the appropriate efforts in surveillance and control measures (Panetta and Roger 2005; Panetta 2007). As pointed out by Panetta and Lawes (2007), a 
fundamental criterion for evaluating eradication success is an accurate delimitation of an invasion (defined as the determination of its full spatial extent), because unless the invasion has been delimited, undetected infestations will continue to expand and give rise to additional foci of infestation. Nevertheless, eradication success at the national level is not impossible: In our study, $32 \%$ of national campaigns were successful.

Eradications on islands were not more successful than those on the mainland. Hence for plant pests and weeds at least, eradication chances seem equal on mainland and on island sites and the actual infestation size is of higher importance than insularity.

As for reaction time and the level of preparedness, it might not be the time or the contingency plan itself that matter, but rather the degree of implementation of the plan. For instance, in the campaigns in our dataset, authorities usually reacted quickly (74\% within the first year), but such campaigns were not more likely to succeed than those with slow reaction times. The lack of any relationship between the level of biological knowledge and the outcome of the campaign might mean that having a contingency plan is not in itself enough for successful eradication or does not fully reflect the level of knowledge available. Hence, using the existence of a PRA or a contingency/eradication plan as an indicator for available knowledge might be too coarse a variable, because aspects of the ecology of species and management actions are mixed. We conclude that having a contingency or eradication plan is no guarantee for success, nor should lack of knowledge about the species be an excuse for inaction. In a next step, we suggest to evaluate the degree of implementation of a contingency or eradication plan: Having the authority to enforce cooperation and dedicated project leaders, thus insuring that an eradication plan is implemented, are also key for success (Simberloff 2009). However, indices to measure the degree of implementation are still missing and could be developed in collaboration with economists.

An average success rate of $49 \%$ to eradicate plant pests and weeds may appear high, but it supports Simberloff's argument that eradication success may often go unnoticed while failures are well publicized (Simberloff 2009). One could argue that the high success rate might be due to the dominance in the dataset $(62 \%)$ of mainly agricultural pests that were repeatedly successfully eradicated, such as the Colorado potato beetle (Leptinotarsa decemlineata)
(Bartlett 1979), several fruit flies species or the bacterial and virus diseases in our dataset (Table 1). Many of these infestations occurred in artificial or protected environments, and as such may have been easier to eradicate than invasive species occupying natural habitats. However, compared to other eradication databases the success rates reported here do not seem high. The Global Island Invasive Vertebrate Eradication Database (www.islandconservation.org; accessed Oct. 2011) lists 952 attempts of vertebrate eradications of which 784 were classified as successes and only 88 as failures ( $89.9 \%$ successes). Howald et al. (2007) report similarly high success rates varying between 95\% (Norway rats, Rattus norvegicus) and $81 \%$ (house mice, Mus musculus) for rodent eradication attempts on islands. However, for weed eradications on the Galapagos islands success rates of only $13 \%$ have been reported (Gardener et al. 2010). The present study is the first to quantitatively analyze eradication campaigns against plant pests and weeds; similar analyses on taxonomic groups not included here are currently lacking, but they would be necessary to judge if patterns found here are general. For example, it might be worthwhile to test economic and ecological pests separately. Such a restriction of the target system will reduce potential sources of variation due to differing habitat properties or heterogeneous stakeholder interests and allow gaining deeper insights into the role of factors determining eradication success.

The lack of support for an effect of reaction time, the level of knowledge/preparedness and insularity in our study does not necessarily mean that these factors are never relevant for eradication success. It could be argued that their non-significance is caused by the limited size of the dataset or by a large variation within the data. However, two expected sources of variation (differences due to taxonomy and biogeographic regions) had no significant effect on eradication success.

While no differences were found in eradication success between the main biogeographic regions Europe, America and Australasia, it can still be expected that a country's invasive species policy and the amount of resources it invests in this issue affect eradication success. We did not attempt to capture such socioeconomic aspects of eradications in this study, although we are aware of their potentially critical importance for an efficient invasive species 
management (Keller et al. 2009). Optimal resource allocation in prevention (surveillance) and control have been modeled by several authors and for different organisms and ecosystems such as the Zebra mussel (Dreissena polymorpha) (Leung et al. 2002) or orange hawkweed (Hieracium aurantiacum) (Hauser and McCarthy 2009). A recent review found that a management objective explicitly considering both costs and damages is most appropriate for determining economically optimal strategies, but faces challenges due to uncertainty (Epanchin-Niell and Hastings 2010). Instead of capturing a country's invasive species policy or optimal resource allocation, we attempted to collate information about actual eradication costs (monetary costs and manpower involved). However, this kind of information was available in only $35 \%$ (monetary costs) and $15 \%$ (manpower) of the cases, and had thus to be discarded from the quantitative analysis. This is a serious shortcoming in our knowledge of eradication projects. In the absence of more precise figures, an economic indicator like Gross Domestic Product of the country in which a campaign was carried out as a proxy for funding efforts could be used instead. Nonetheless, we encourage pest managers to thoroughly collect and communicate eradication costs for future research and thus also provide a basis for future cost-benefit analyses.

Acknowledgments We thank Richard Baker, Andrea Battisti, Marc Kenis, Nico van Opstal, Marc Cadotte and four anonymous reviewers for helpful comments on previous drafts of this paper and Sylvie Augustin, Peter Baufeld, Annemarie Breukers, Eckehard Brockerhoff, Mark Bullians, Louise Dumouchel, Dominic Eyre, Ben Gasman, Salla Hannunen, Katrin Kaminski, Olia Karadjova, John Kean, Hella Kehlenbeck, William Larkin, Lorenzo Marini, Sharon Matthews-Berry, Anthemis Melifronidou, Petra Mueller, Melanie Newfield, Mary Orr, Grant Telford, Sunil Singh, Edoardo Petrucco Toffolo, Olivier Pruvost, Serge Quirici, Peter Reed, Cécile Robin, Muriel Suffert, Dirk Jan van der Gaag, Peter Whittle, and Annie Yart for providing information on eradication campaigns. Work on this paper was supported by the European Commission under grant agreement number KBBE-212459, 7th Framework Programme, project PRATIQUE: Enhancement of Pest Risk Analysis Techniques. V.J., J.P. and P.P. were further supported by grants 206/09/0563, 504/11/1028 (Czech Science Foundation), AV0Z60050516, IAA600050811 (Academy of Sciences of the Czech Republic), MSM0021620828 and LC06073 (Ministry of Education, Youth and Sports of the Czech Republic). P.P. acknowledges support from a Praemium Academiae award from the Academy of Sciences of the Czech Republic.

\section{References}

Baker RHA, Battisti A, Bremmer J, Kenis M, Mumford J, Petter F, Schrader G, Bacher S, De Barro P, Hulme PE, Karadjova O, Lansink AO, Pruvost O, Pyšek P, Roques A, Baranchikov Y, Sun JH (2009) PRATIQUE: a research project to enhance pest risk analysis techniques in the European Union. EPPO/OEPP Bull 39:87-93

Bartlett PW (1979) Preventing the establishment of Colorado beetle in England and Wales. In: Ebbels DL, King JE (eds) Plant Health. Blackwell Scientific Publications, Oxford, pp 247-257

Bates D, Maechler M, Dai B (2008) lme4: Linear mixed-effects models using S4 classes. http://lme4.r-forge.r-project.org/

Bogich TL, Liebhold AM, Shea K (2008) To sample or eradicate? A cost minimization model for monitoring and managing an invasive species. J Appl Ecol 45(4):1134-1142

Bolker BM, Brooks ME, Clark CJ, Geange SW, Poulsen JR, Stevens MHH, White J-SS (2009) Generalized linear mixed models: a practical guide for ecology and evolution. Trends Ecol Evol 24(3):127-135

Bomford M, O'Brien P (1995) Eradication or control for vertebrate pests? Wildl Soc Bull 23(2):249-255

Brockerhoff EG, Liebhold AM, Richardson B, Suckling DM (2010) Eradication of invasive forest insects: concepts, methods, costs and benefits. NZ J For Sci 40:S117-S135

Burnham K, Anderson D (2002) Model selection and multimodel inference: a pratical information-theoric approach, 2nd edn. Springer, New York

Clout MN, Veitch CR (2002) Turning the tide of biological invasion: the potential for eradicating invasive species. IUCN SSC Invasive Species Specialist Group, Gland and Cambridge

Courchamp F, Chapuis J, Pascal M (2003) Mammal invaders on islands: impact, control and control impact. Biol Rev 78(3): 347-383

Dahlsten DL, Garcia R (1989) Eradication of exotic pests: analysis with case histories. Yale University Press, New Haven

Davies CE, Moss D (2003) EUNIS habitat classification. European Topic Centre on Nature Protection and Biodiversity, Paris

Epanchin-Niell RS, Hastings A (2010) Controlling established invaders: integrating economics and spread dynamics to determine optimal management. Ecol Lett 13(4):528-541

FAO (2004) Pest risk analysis for quarantine pests, including analysis of environmental risks and living modified organisms (ISPM 11). International standards for phytosanitary measures. FAO, Rome

FAO (2007) Glossary of phytosanitary terms (ISPM 5). International standards for phytosanitary measures. FAO, Rome

Gardener M, Atkinson R, Rentería J (2010) Eradications and people: lessons from the plant eradication program in Galapagos. Restor Ecol 18(1):20-29

Genovesi P (2005) Eradications of invasive alien species in Europe: a review. Biol Invasions 7(1):127-133

Genovesi P (2007) Limits and potentialities of eradication as a tool for addressing biological invasions. In: Nentwig W (ed) Biological invasions, ecological studies 193. Springer, Berlin, Heidelberg, pp 385-402 
Hauser CE, McCarthy MA (2009) Streamlining 'search and destroy': cost-effective surveillance for invasive species management. Ecol Lett 12(7):683-692

Howald G, Donlan C, Galvan JP, Russell JC, Parkes J, Samaniego A, Wang Y, Veitch D, Genovesi P, Pascal M (2007) Invasive rodent eradication on islands. Conserv Biol 21(5): 1258-1268

Hulme PE (2006) Beyond control: wider implications for the management of biological invasions. J Appl Ecol 43(5): 835-847

Hulme PE (2009) Trade, transport and trouble: managing invasive species pathways in an era of globalization. J Appl Ecol 46(1):10-18

Keller R, Lodge D, Lewis M, Shogren J (2009) Bioeconomics of invasive species: integrating ecology, economics, policy, and management. Oxford University Press, New York

Kettunen M, Genovesi P, Gollasch S, Pagad S, Starfinger U, Brink Pt, Shine C (2009) Technical support to EU strategy on invasive alien species (IAS) - assessment of the impacts of IAS in Europe and the EU. Institute for European Environmental Policy, Brussels

Leung B, Lodge D, Finnoff D, Shogren J, Lewis M, Lamberti G (2002) An ounce of prevention or a pound of cure: bioeconomic risk analysis of invasive species. Proc R Soc Lond B Biol Sci 269(1508):2407

Liebhold A, Bascompte J (2003) The Allee effect, stochastic dynamics and the eradication of alien species. Ecol Lett 6(2):133-140

Mack RN, Lonsdale WM (2002) Eradicating invasive plantshard-won lessons from islands. In: Veitch CR, Clout M (eds) Turning the tide: the eradication of invasive species. IUCN SSC Invasive Species Specialist Group, Gland and Cambridge, pp 164-172

Manchester SJ, Bullock JM (2000) The impacts of non-native species on UK biodiversity and the effectiveness of control. J Appl Ecol 37(5):845-864

Mazerolle MJ (2011) AICcmodavg: model selection and multimodel inference based on (Q)AIC(c). R package version 1.18. http://CRAN.R-project.org/package=AICcmodavg

Myers JH, Simberloff D, Kuris AM, Carey JR (2000) Eradication revisited: dealing with exotic species. Trends Ecol Evol 15(8):316-320

Nentwig W, Kühnel E, Bacher S (2010) A generic impactscoring system applied to alien mammals in Europe. Conserv Biol 24:302-311

Opstal NAV, Sunley R (2009) EPPO workshop on eradication, containment and contingency planning. EPPO Bull 39(2): $143-145$

Panetta FD (2007) Evaluation of weed eradication programs: containment and extirpation. Divers Distrib 13(1):33-41

Panetta F, Lawes R (2007) Evaluation of the Australian branched broomrape (Orobanche ramosa) eradication program. Weed Sci 55(6):644-651

Panetta FD, Roger L (2005) Evaluation of weed eradication programs: the delimitation of extent. Divers Distrib 11(5): 435-442

Pyšek P, Richardson D (2010) Invasive species, environmental change and management, and health. Annu Rev Environ Resour 35:25-55
Regan TJ, McCarthy MA, Baxter PWJ, Panetta FD, Possingham HP (2006) Optimal eradication: when to stop looking for an invasive plant. Ecol Lett 9(7):759-766

Rejmánek M, Pitcairn MJ (2002) When is eradication of exotic pest plants a realistic goal? In: Veitch CR, Clout MN (eds) Turning the tide: the eradication of invasive species. IUCN SSC Invasive Species Specialist Group, Gland and Cambridge, pp 249-253

Richards SA (2005) Testing ecological theory using the information-theoretic approach: examples and cautionary results. Ecology 86(10):2805-2814

Richards SA (2008) Dealing with overdispersed count data in applied ecology. J Appl Ecol 45(1):218-227

Robertson BC, Gemmell NJ (2004) Defining eradication units to control invasive pests. J Appl Ecol 41(6):1042-1048

Rout TM, Salomon Y, McCarthy MA (2009a) Using sighting records to declare eradication of an invasive species. J Appl Ecol 46(1):110-117

Rout TM, Thompson CJ, McCarthy MA (2009b) Robust decisions for declaring eradication of invasive species. J Appl Ecol 46(4):782-786

Shine C, Kettunen M, Genovesi P, Essl F, Gollasch S, Rabitsch W, Scalera R, Starfinger U, Ten Brink P (2010) Assessment to support continued development of the EU strategy to combat invasive alien species. Final report for the European commission. Institute for European Environmental Policy, Brussels

Simberloff D (2003a) Eradication-preventing invasions at the outset. Weed Sci 51(2):247-253

Simberloff D (2003b) How much information on population biology is needed to manage introduced species? Conserv Biol 17(1):83-92

Simberloff D (2008) We can stop the invasion juggernaut!high- and low-tech success stories. Neobiota 7:5-18

Simberloff D (2009) We can eliminate invasions or live with them. Successful management projects. Biol Invasions 11(1):149-157

Simberloff D, Genovesi P, Pysek P, Campbell K (2011) Recognizing conservation success. Science 332(6028):419

Sosnowski MR, Fletcher JD, Daly AM, Rodoni BC, ViljanenRollinson SLH (2009) Techniques for the treatment, removal and disposal of host material during programmes for plant pathogen eradication. Plant Pathol 58(4):621-635

Suckling DM, Barrington AM, Chhagan A, Stephens AEA, Burnip GM, Charles JG, Wee SL (2007) Eradication of the Australian painted apple moth Teia anartoides in New Zealand: trapping, inherited sterility, and male competitiveness. In: Vreysen MJB, Robinson AS, Hendrichs J (eds) Areawide control of insect pests. Springer, Dordrecht, pp 603-615

R Development Core Team (2008) R: a language and environment for statistical computing. $\mathrm{R}$ foundation for statistical computing, Vienna, Austria. ISBN 3-900051-07-0, URL http://www.R-project.org

Tobin PC, Berec L, Liebhold AM (2011) Exploiting Allee effects for managing biological invasions. Ecol Lett 14:615-624

Vercken E, Kramer AM, Tobin PC, Drake JM (2011) Critical patch size generated by Allee effect in gypsy moth, Lymantria dispar (L.). Ecol Lett 14(2):179-186 
Vilà M, Basnou C, Pyšek P, Josefsson M, Genovesi P, Gollasch S, Nentwig W, Olenin S, Roques A, Roy D, Hulme PE (2009) How well do we understand the impacts of alien species on ecosystem services? A pan-European, crosstaxa assessment. Front Ecol Environ 8(3):135-144

Winter M, Schweiger O, Klotz S, Nentwig W, Andriopoulos P, Arianoutsou M, Basnou C, Delipetrou P, Didžiulis V,
Hejda M (2009) Plant extinctions and introductions lead to phylogenetic and taxonomic homogenization of the European flora. Proc Natl Acad Sci USA 106(51):21721-21725

Zuur A, Ieno E, Walker N, Saveliev A, Smith G (2009) Mixed effects models and extensions in ecology with R. Springer, New York 